\title{
Atık Yapan Sığırlarda Anti-Neospora caninum Antikorlarının Yaygınlığının Araştırılması
}

\author{
Ufuk Erol, Erdem Danyer, Selim Tuncer, Çağla Korkmaz, Ahmet Deniz \\ Veteriner Kontrol Merkez Araştırma Enstitüsü, Parazitoloji Laboratuvarl, Ankara.
}

Geliş Tarihi / Received: 04.04.2019, Kabul Tarihi / Accepted: 10.05.2019

\begin{abstract}
Özet: Bu araştırma sığırların önemli atık etkenlerinden biri olan Neospora caninum'un atık yapmış sığırlardaki yaygınlığının araştırılması amacıyla yapıldı. Bu amaçla, atık geçmişi ile Veteriner Kontrol Merkez Araştırma Enstitüsü Müdürlüğü'ne 25 ilden gönderilen 986 sığır kan serumu N. caninum antikorları yönünden competitive ELISA (c-ELISA) ile tarandı ve örneklerde \%32,35 (319/986) oranında $N$. caninum tespit edildi. Sı̆̆ır çiftliklerinde $N$. caninum kaynaklı enfeksiyonlarda atıklara ilave olarak süt verimlerinde azalmaya, döl tutma problemine bağlı olarak erken damızlıktan çıkarmaya ve persiste enfekte buzağıların doğmasına neden olarak ciddi ekonomik kayıplara yol açmaktadır.
\end{abstract}

Anahtar kelimeler: c-ELISA, Neospora caninum, sığır,

\section{Distribution of Anti-Neospora caninum Antibodies in Cattle with Abortion History}

\begin{abstract}
This study was carried out to investigate the distribution of Neospora caninum which is a crucial aborting agent in cattle breeding. For this purpose, 986 cattle serum samples, sent to Veterinary Control Central Research Institute from 25 different provinces in Turkey with abortion history, were tested with Competitive ELISA (c-ELISA) and anti-N. caninum antibodies were detected from 32.35\% (319/986) of the samples. In addition to abortion in cattle, $N$. caninum causes economic losses in dairy and beef cattle farms due to reduction in milk yield, early separation from breeding by reason of reproductive disorders and persistently infected calf births.
\end{abstract}

Key words: c-ELISA, cattle, Neospora caninum

\section{Giriş}

Neospora caninum, Toxoplasmatidae ailesinde yer alan zorunlu hücre içi protozoal etkendir. Etken ilk defa 1984 yılında Norveç'te yavru köpeklerde merkezi sinir sistemi ve iskelet kaslarında yang1 olgularında tespit edilmiş ve tür teşhisi yapılamadığ 1 için "teşhis edilememiş sporozoon kist" olarak tanımlanmıştır [9]. Sonraki yıllarda ABD'de toxoplasmosis benzeri hastalık belirtileri gösteren $23 \mathrm{kö-}$ peğin 10'unda etkene rastlanmış, etkenin yapısal ve antijenik özelliklerinin Toxoplasma gondii'den farklı olması nedeniyle Neospora caninum olarak isimlendirilmiştir [13].

Neospora caninum'un son konağının kanideler (köpek, çakal gibi), ara konağının ise başlıca sığırlar, nadiren de koyun, keçi, at ve köpek olduğu bildirilmiştir $[15,16]$. Son yıllarda yapılan çalışmalar, bazı kanatlı türlerinin de $N$. caninum'un ara konağ olabileceğini ortaya koymuştur. [1, 10, 11]. Etken ayrica insan olmayan primatlar [4], kanguru [24] ve rodentlerde de [25] tespit edilmiştir.
Etkenin biyolojisinde, ara konak ve son konaklarda enfeksiyona neden olan üç ayrı (takizoit, bradizoit ve ookist) form bulunmaktadir. Son konakların dişkılarıyla atılan sporlanmamış ookistler dış ortamda yaklaşık 24 saat içerisinde sporlanarak ara konaklar için enfektif hale dönüşür. Ara konaklar yemde, suda ya da toprakta bulunan sporlanmış ookistleri alarak enfeksiyona yakalanırlar Yine gebe ineklerde, etken endojen transplasental yolla \%90'lara kadar yüksek oranda yavruya geçebilir ve gebeliğin dönemine bağlı olarak abort ya da enfekte buzağ 1 doğumlarına yol açabilmektedir $[12,15]$.

Neospora caninum ara konak sığırlarda atıklara neden olduğu için veteriner hekimlik açısında oldukça önemlidir. Meksika'da 1987 y1lında ilk kez bir süt çiftliğinde atıklar Bovine neosporosis ile ilişkilendirilmiş ve daha sonrasında da birçok atık vakasında etken ile karşılaşılmıştır [6]. Gebe sığırlarda etkenin vertikal yolla yavruya geçmesi sonucunda atığa, konjenital bozukluklara sahip (koordinasyon bozukluğu, tremor ve ekstremitelerde hiperekstansiyon gibi) ya da persiste enfekte buzağıların 
doğmasına, döl tutmaması sonucunda damızlıktan ayrılmaya ve süt veriminin azalmasına yol açmas1 nedenleriyle neosporiosis sığır yetiştiriciliğinde ciddi ekonomik kayıplara neden olmaktadır $[6,12$, $15,16]$.

Sı̆̆ırlarda N. caninum'un yaygınlı̆̆ının araştırılması amacıyla yapılan çalışmalar incelendiğinde etkenin teşhisinde yoğun olarak ELISA ve IFA testlerinin kullanılmakta olduğu görülmüştür $[7,15,17$, 21]. Dünya'da sığırlarda $N$. caninum'un yaygınlığ1nın araştırılması amacıyla yapılan serolojik çalışmalar incelendiğinde, etkenin altı kıtada da görüldüğü ve yaygınlığının kıtalara göre Kuzey Amerika'da \%5,2-79, Güney Amerika' da \%3,9-97,2, Avrupa'da $\% 0,7-65$, Asya'da \%5,5-70, Afrika'da \%8,96-20,4 ve Avustralya'da \%7,6-53 olduğu görülmektedir [7, $8,14,15,18,21,22,23,27,28]$.

Türkiye'de sığırlarda $N$. caninum'un yaygınlığının araştırılması amacıyla yapılan serolojik çalışmaların hemen tamamında ticari ELISA testinin kullanıldığ1 görülmüş ve bu çalışmalarda $N$. caninum'un yaygınlığının, Sakarya'da \%9,2 [30], Kırıkkale'de, İzmir'de ve Tokat'ta \%10,77 [36], Ankara'da \%10,15, Çankırı' da \%6,93, Nevşehir'de $\% 5,10$, Eskişehir'de \%5,43, Yozgat'ta \%20,32 [34], Kayseri'de \%7-10,82 [19, 34], Kırşehir'de \%18,119,55 [34, 35], Kirkkale'de \%32,72-66,66 [29, 34], Burdur'da \%21,97, Aksaray'da \%34,9 [29, 34], Kars'ta \%2-7,2 [2, 26], Van'da \%4,88 [5], Şanlıurfa'da \%7,5 [31], Adana'da \%10,7 [17], Elazı ğ'da $\% 8,19-15$ [3,33], Malatya'da \%4, Muş'ta \%4,86 ve Bingöl'de \%4,69 [3] olduğu bildirilmiştir.

Çalışmanın amacı, Türkiye'nin 25 ilinden Veteriner Kontrol Merkez Araştırma Enstitüsü Müdürlüğü'ne gönderilmiş olan atık yapmış sığır kan serumlarında $N$. caninum'un yaygınlığının araştırılmasidir.

\section{Materyal ve Metot}

Çalışma materyalini, N. caninum varlığı yönünden incelenmesi amaciyla Veteriner Kontrol Merkez Araştırma Enstitü Müdürlüğü'ne gönderilmiş olan atık yapmış 986 sığıra ait kan serum örneği oluşturmaktadır. Serum örnekleri toplamda 25 ilden, soğuk zincir şartları altında gönderilmiştir. Örneklerin gönderildiği iller ve örnek sayıları Tablo 1'de verilmiştir. Serum örneklerinde N. caninum antikorlarının aranması için compatative ELISA (cELISA)
$\left(\mathrm{VMRD}^{\circledR}\right.$, Pullman, ABD) kiti üretici firma talimatlarına göre kullanılmıştır.

Sonuçlar Excel ${ }^{\circledR} \quad$ Microsoft $^{\circledR}$, V.2016, Washington, ABD) programıla kayıt altına alınmış ve SPSS $^{\circledR}\left(\mathrm{IBM}^{\circledR}\right.$, V. 21, Armonk, NY, ABD) programıyla sonuçların istatistiksel değerlendirilmiştir. Levene's Test ile varyansların homojenliği kontrol edilmiştir. Pozitif ve negatif numuneler arasındaki önem farkı Bağımsız örneklem t-testi ile değerlendirilmiştir. İstatistik analizleri için önem sınırı $\mathrm{p}<0,05$ olarak kabul edilmiştir.

\section{Bulgular}

Tablo 1. Atık yapan sığır numunelerinin illere göre dağllimı.

\begin{tabular}{|c|c|c|c|c|}
\hline \multicolumn{2}{|c|}{ Sıra No İl } & \multirow{2}{*}{$\begin{array}{c}\begin{array}{l}\text { Toplam } \\
\text { Numune }\end{array} \\
16\end{array}$} & \multirow{2}{*}{$\begin{array}{l}\begin{array}{l}\text { Pozitif } \\
\text { Numune }\end{array} \\
4\end{array}$} & \multirow{2}{*}{$\begin{array}{c}\begin{array}{c}\text { Pozitiflik } \\
\text { Oranı (\%) }\end{array} \\
25,00\end{array}$} \\
\hline 1 & Adana & & & \\
\hline 2 & Aksaray & 307 & 162 & 52,77 \\
\hline 3 & Ankara & 14 & 1 & 7,14 \\
\hline 4 & Bartın & 2 & 0 & 0,00 \\
\hline 5 & Bursa & 33 & 3 & 9,09 \\
\hline 6 & Çankırı & 11 & 1 & 9,09 \\
\hline 7 & Çorum & 5 & 2 & 40,00 \\
\hline 8 & Denizli & 3 & 0 & 0,00 \\
\hline 9 & Erzincan & 11 & 0 & 0,00 \\
\hline 10 & Erzurum & 3 & 0 & 0,00 \\
\hline 11 & Eskişehir & 8 & 3 & 37,50 \\
\hline 12 & İstanbul & 8 & 0 & 0,00 \\
\hline 13 & İzmir & 13 & 3 & 23,08 \\
\hline 14 & Kastamonu & 23 & 2 & 8,70 \\
\hline 15 & Kırıkkale & 147 & 23 & 15,65 \\
\hline 16 & Kırklareli & 25 & 4 & 16,00 \\
\hline 17 & Kırşehir & 4 & 0 & 0,00 \\
\hline 18 & Malatya & 6 & 1 & 16,67 \\
\hline 19 & Manisa & 10 & 1 & 10,00 \\
\hline 20 & Muğla & 100 & 32 & 32,00 \\
\hline 21 & Sakarya & 4 & 0 & 0,00 \\
\hline 22 & Samsun & 10 & 2 & 20,00 \\
\hline 23 & Siirt & 2 & 0 & 0,00 \\
\hline 24 & Şanlıurfa & 201 & 67 & 33,33 \\
\hline 25 & Tekirdağ & 20 & 8 & 40,00 \\
\hline & oplam & 986 & 319 & 32,35 \\
\hline
\end{tabular}

Çalışmamızda incelenen 986 sığır kan serumunun 319 (\%32,35)'unda $N$. caninum tespit edilmiştir. 
Sonuçların illere göre dağılımı ve yüzde pozitiflik değerleri Tablo-1'de gösterilmektedir.

Ülkemizde yapılan diğer çalışmalar ile karşılaştırıldığında çalışmamızın örneklem büyüklüğü $(p=0,50)$ ve pozitiflik sayısı $(p=0,80)$ önceki çalışmalarla uyumlu bulunmuştur.

\section{Tartıșma ve Sonuç}

Neospora caninum, dünya genelinde sığırlarda atıklara neden olan en önemli etkenlerden biri olup, bunun yanında sığırlarda konjenital hasarlı buză̆ $1-$ ların doğmasına veya bazen de herhangi bir klinik belirti göstermeyen ancak $N$. caninum ile enfekte buzağıların doğmasına neden olmaktadır $[12,15]$. Enfekte doğan bu hayvanların ilerleyen dönemlerde gebe kaldıklarında atık yapma ihtimalinin, etken ile karşılaşmamış hayvanlara göre yaklaşık iki kat daha fazla olduğu bildirilmiștir [15].

$\mathrm{Bu}$ çalışmada, atık yapmış sığırların \%32,35'inde $N$. caninum tespit edilmiștir. Çalıșma sonucu, çeşitli ülkelerde atık yapan sığırlarda N. caninum yaygınlığının c-ELISA ile araştırıldı ğı çalışmalarla karşılaştırıldığında, Bulgaristan'dan (\%10) [15], Çekya'dan $(\% 0,5-3,9)[8,15]$, Polonya'dan $(\% 15,6)$ [15], Slovakya $(\% 22,2)$ 'dan [15], Surbistan'dan $(\% 7,2-15,4)[22,23]$, Romaya'dan $(\% 27,7)$ [20] ve Sudan'dan $(\% 10,7)$ [18], daha yüksek bulunmuşken, yine bu oranın Brezilya'dan $(\% 42,1)$, Meksika'dan (\%42-59), ABD'den (\%79), Portekiz'den (\%49), İspanya'dan $(\% 35,4)$, İsveç'ten (\%63), Birleşik Krallık (\%60), Yeni Zelenda (\%5053)'dan [15] ve Pakistan'dan (\%43) [27] daha düşük olduğu görülmüştür.

Ülkemizde şimdiye kadar yapılan çalışmalar incelendiğinde, atık geçmişi olan sığırlarda $N$. caninum'un yaygınlığının araştırılması amacıyla yapılmış yalnızca iki çalışma tespit edilmiştir. Bu çalışmaların birinde 134 sı ğırın \%35,7'sinin [31], diğerinde ise Kırkkkale, Burdur ve Aksaray illerindeki 427 sığırın \%37,7'sinin kan serumunda $N$. caninum tespit edilmiştir [29]. Bu çalışmada ise atık yapan 986 sı̆̆ırın \%32,35'inin kan serumunda $N$. caninum tespit edilmiş ve sonuç bu çalışmalar ile karşılaştırıldığında pozitiflik oranının daha düşük olduğu görülmüştür. Neospora caninum'un yaygınlığının araştırılması amacıyla yapılan diğer çalışmalarda ise, örneklemenin bir bölgedeki sığırların tesadüfi olarak örneklenmesi ile oluşturulduğu görülmüş ve bu nedenle çalışma sonuçlarımız bu çalışmaların sonuçları ile karşılaştırılamamıştır.

Neospora caninum'un yaygınlığının belirlenmesi amacıyla yapılan çalışmalarda elde edilen pozitiflik oranlarındaki farklılık nedenleri, sürü yönetimine, hayvanların beslenme ve barınma şekillerine, sürü büyüklüğüne, iklime, hayvanların temin edilme șekline ve hayvan 1rkına bağlı olduğu belirtilmektedir [15].

Çalışma sonucunda atık yapan 986 sığırların $\% 32,35$ 'inde $N$. caninum antikorlarının tespit edilmesi kayda değer bir veri olup, sığır atık vakalarında $N$. caninum'un göz ardı edilmemesi gerektiğini düşündürmektedir. $\mathrm{Bu}$ nedenle atık vakaları değerlendirilirken sığırlarda atıklara neden olan diğer etkenlerle birlikte $N$. caninum yönünden de analiz yaptırılması ve sonuçların değerlendirilmesi oldukça önemlidir. Sı ğırlarda atık vakalarının yanı sıra; persiste enfekte buzağ doğması, süt veriminde azalma ve erken damızlıktan çıkarma gibi ciddi ekonomik kayıplara neden olan $N$. caninum 'un, ülkemizdeki gerçek yaygınlığının belirlenebilmesi için önceki çalışmalara ek olarak ülkesel çapta epidemiyolojik bir çalışma gerektiği düşünülmektedir.

\section{Kaynaklar}

1. Abdoli A, Arbabi M, Pirestani M, Mirzaghavami M, Ghaffarifar F, Dalimi A, Sadraei J (2018). Molecular assessment of Neospora caninum and Toxoplasma gondii in hooded crows (Corvus cornix) in Tehran, Iran. Comparative Immunology, Microbiology and Infectious Diseases. 57, 69-73.

2. Akca A, Gokce HI, Guy CS., McGarry JW, Williams DJ (2005). Prevalence of antibodies to Neospora caninum in local and imported cattle breeds in the Kars province of Turkey. Research in veterinary science, 78(2), 123-126.

3. Aktaş M, Şaki CE, Altay K, Şimşek S, Ütük AE, Köroğlu E, Dumanlı N (2005). Doğu Anadolu bölgesinin bazı illerinde bulunan sığırlarda Neospora caninum'un araştırllmast. Türkiye Parazitol Derg, 29(1), 22-25.

4. Akue JP, Tomo NE, Badiambile J, Moukana H, MbouMountsimbi RA, Ngoubangoye B (2018). Seroprevalence of Toxoplasma gondii and Neospora caninum in non-human primates at a primate center at Franceville, Gabon. Journal of Parasitology and Vector Biology, 10(1), 1-7.

5. Alan M, Cetin Y, Sendag S, Akkan HA, Karaca M (2011). Seroprevalence of Antibodies Against Neospora caninum in Cows in Van Province. Kafkas üniversitesi Veteriner Fakültesi Dergisi, 17(5), 767-771.

6. Anderson ML, Andrianarivo AG, Conrad PA (2000). Neosporosis in cattle. Animal reproduction science, 60, 417431. 
7. Asmare K, Regassa F, Robertson LJ, Skjerve E (2013). Seroprevalence of Neospora caninum and associated risk factors in intensive or semi-intensively managed dairy and breeding cattle of Ethiopia. Veterinary parasitology, 193(13), 85-94.

8. Bártová E, Sedlák K, Budíková M (2015). A study of Neospora caninum and Toxoplasma gondii antibody seroprevalence in healthy cattle in the Czech Republic. Ann Agric Environ Med, 22, 32-34.

9. Bjerkas I, Mohn SF, Presthus J (1984). Unidentified cystforming sporozoon causing encephalomyelitis and myositis in dogs. Zeitschrift für Parasitenkunde, 70(2), 271-274.

10. Darwich L, Cabezón O, Echeverria I, Pabón M, Marco I, Molina-López R, Alarcia-Alejos O, López-Gatius F, Lavín S, Almería S. (2012). Presence of Toxoplasma gondii and Neospora caninum DNA in the brain of wild birds. Veterinary Parasitology, 183(3-4), 377-381.

11. De Barros LD, Miura AC, Minutti AF, Vidotto O, Garcia JL (2018). Neospora caninum in birds: A review. Parasitology international. 67(4), 397-402.

12. Dubey JP (2003). Review of Neospora caninum and neosporosis in animals. The Korean journal of parasitology, 41(1), 1.

13. Dubey JP, Carpenter JL, Speer CA, Topper MJ, ANDA U (1988). Newly recognized fatal protozoan disease of dogs. Journal of the American Veterinary Medical Association, 192(9), 1269-1285.

14. Dubey JP, Schares G (2011). Neosporosis in animals the last five years. Veterinary parasitology, 180(1-2), 90-108.

15. Dubey JP, Schares G, Ortega-Mora LM (2007). Epidemiology and control of neosporosis and Neospora caninum. Clinical microbiology reviews, 20(2), 323-367.

16. Dumanlı N, Aktaş M (2015). Toxoplasmatidae (Toxoplasma, Neospora). Dumanl1 N, Karaer KZ. Eds. Veteriner Protozooloji. Medisan Yayinevi, Ankara. p.133-150.

17. Eşki F, Ütük AE (2018). Detection of anti-Neospora caninum antibodies in cattle in Adana province of Turkey. Van Veterinary Journal, 29(2), 93-99.

18. Ibrahim AME, Elfahal AM, Hussein ARME (2012). First report of Neospora caninum infection in cattle in Sudan. Trop Anim Health Prod, 44, 769-772.

19. İça A, Yıldırım A, Düzlü Ö, İnci A (2006). Kayseri yöresinde siğırlarda Neospora caninum'un seroprevalanst. Türkiye Parazitol Derg, 30(2), 92-94.

20. Imre K, Morariu S, Ilie MS, Imre M, Ferrari N, Genchi C, Darabus G (2012). Serological survey of Neospora caninum infection in cattle herds from western Romania. J Parasitol, 98, 683-685. (Romanya \%27,7).

21. Kamga-Waladjo AR, Gbati OB, Kone P, Lapo RA, Chatagnon G, Bakou SN, Pangui LJ, Diop PEH, Akakpo JA, Tainturier D (2010). Seroprevalence of Neospora caninum antibodies and its consequences for reproductive parameters in dairy cows from Dakar-Senegal, West Africa. Tropical animal health and production, 42(5), 953-959.

22. Klun I, Ćirković V, Maletić M, Bradonjić S, DjurkovićDjaković O (2019). Seroprevalence of Neospora caninum infection and associated risk factors in dairy cattle in Serbia. Parasitology research, 1-9.
23. Kuruca L, Spasojević-Kosić L, Simin S, Savović M, Laus S, Lalosević V (2013). Neospora caninum antibodies in dairy cows and domesic dogs from Vojvodina, Serbia. Parasite, 20, 40.

24. Mayberry C, Maloney SK, Mitchell J, Mawson PR, Bencini R (2014). Reproductive implications of exposure to Toxoplasma gondii and Neospora caninum in western grey kangaroos (Macropus fuliginosus ocydromus). Journal of wildlife diseases, 50(2), 364-368.

25. Meerburg BG, De Craeye S, Dierick K, Kijlstra A (2012). Neospora caninum and Toxoplasma gondii in brain tissue of feral rodents and insectivores caught on farms in the Netherlands. Veterinary Parasitology, 184(2-4), 317-320.

26. Mor N, Akça A (2012). Kars Yöresinde siğır ve köpeklerde Neospora caninum üzerine epidemiyolojik araştırmalar: gruplar arası çalışma. Kafkas üniversitesi veteriner fakültesi dergisi, 18, 193-199.

27. Nazir MM, Maqbool A, Khan MS, Sajjid A, Lindsay DS (2013). Effects of age and breed on the prevalence of Neospora caninum in commercial dairy cattle from Pakistan. J Parasitol, 99, 368-370.

28. Njiro SM, Kidanemariam AG, Tsotetsi AM, Katsande TC, Mnisi M, Lubisi BA, Potts AD, Baloyi F, Moyo G, Mpofu J, Kalake A, Williams R (2011). A study of some infectious causes of reproductive disorders in cattle owned by resourcepoor farmers in Gauteng Province, South Africa. Journal of the south african veterinary association, 82(4), 213-218.

29. Öcal N, Atmaca HT, Albay MK, Deniz A, Kalender H, Yildiz $\mathrm{K}, \mathrm{Kul} \mathrm{O}$ (2014). A new approach to Neospora caninum infection epidemiology: neosporosis in integrated and rural dairy farms in Turkey. Turkish journal of veterinary and animal sciences, 38(2), 161-168.

30. Öncel T, Bıyıkoğlu G (2003). Sakarya yöresi süt sığırlarında Neosporosis caninum. Uludag Univ J Fac Vet Med, 22, 1-2.

31. Pişkin FÇ, Ütük AE (2009). Ölü doğum ve abort yapan ineklerde Neospora caninum prevalansi. Etlik Vet Mikrobiyol Derg, 20, 23-26.

32. Sevgili M, Altaş MG, Keskin O (2005). Seroprevalence of Neospora caninum in cattle in the province of Şanluurfa. Turkish journal of veterinary and animal sciences, 29(1), 127-130.

33. Simsek S, Utuk AE, Koroglu E, Dumanli N, Risvanli A (2008). Seroprevalence of Neospora caninum in repeat breeder dairy cows in Turkey. Archives animal breeding, 51(2), 143-148.

34. Vural G, Aksoy E, Bozkir M, Kuçukayan U, Erturk, A (2006). Seroprevalence of Neospora caninum in dairy cattle herds in Central Anatolia, Turkey. Veterinarski arhiv, 76(4), 343-349.

35. Yıldız K, Gökpınar S, Sürsal N, Değirmenci R (2017). Seroprevalence of Neospora caninum in Dairy Cattle Raised in Çiçekdaği District of Kırşehir Province. Türkiye parazitoloji dergisi, 41(3), 135.

36. Yildiz K, Kul O, Babur C, Kilic S, Gazyagci AN, Celebi B, Gurcan IS (2009). Seroprevalence of Neospora caninum in dairy cattle ranches with high abortion rate: Special emphasis to serologic co-existence with Toxoplasma gondii, Brucella abortus and Listeria monocytogenes. Veterinary parasitology, 164(2-4), 306-310. 